\title{
Terminology of Aeronautical Meteorology Codes: a systematization by using corpus
}

\author{
Terminologia de códigos de \\ meteorologia aeronáutica: \\ sistematização por meio de corpus
}

"Presence or absence is one thing, but frequency is another."

(TOGNINI-BONELLI 2001: 57)

Rafaela Araújo Jordão Rigaud Peixoto*

* Translator and Researcher at the Department of Airspace Control, Subdepartment of Operations, Standards Division. PhD in Language Studies (PUC-Rio), MA in Linguistics (UFPE) and Graduate Specialist in Translation (UGF). E-mail: rafaelarajrp@decea.gov.br

TradTerm, São Paulo, v.37, n. 1, janeiro/2021, p. 175-204

Número Especial - Linguística de Corpus

www.revistas.usp.br/tradterm 
Abstract: Standardizing terminology is very important to maintain the accuracy of information being disseminated, mainly in specialized fields such as Aeronautical Meteorology. Based on terminology (PAVEL; NOLET 2001; CABRÉ 1999 AND 2003) and corpora (SANTOS 2008 AND 2014; TOGNINI-BONELLI 2011) theoretical foundations, definitions and translation to Portuguese of expressions and terms contained in Table 4678, concerning the main meteorology codes, as prescribed by the World Meteorological Organization (2011), were discussed. As a result, a systematization for terminological procedures is proposed, by using corpora with set validation standards. In this way, this paper intends to contribute to avoid misunderstandings regarding the criticality level of meteorological situations being communicated during air traffic operations.

Keywords: Terminology; Specialized Lexicography; Corpus; Validation; Aviation; Aeronautical Meteorology

Resumo: A padronização de terminologia é muito importante para manter a precisão das informações divulgadas, principalmente em áreas especializadas tais como a Meteorologia Aeronáutica. Com base em pressupostos teóricos de terminologia (PAVEL; Nolet 2001; CABRÉ 1999 e 2003) e de corpora (SANTOS 2008 e 2014; ToGNINIBONELLI 2011), foram discutidas definições e tradução, para o português, de expressões e termos contidos na Tabela 4678, em relação aos principais códigos aeronáuticos, como preconizado pela Organização Mundial de Meteorologia (2011). Como resultado, foi proposta uma sistematização de procedimentos terminológicos, por meio do uso de corpora, para definir padrões de validação. Dessa forma, este artigo pretende contribuir para evitar equívocos em relação ao nível de criticidade de situações meteorológicas comunicadas durante as operações de tráfego aéreo.

Palavras-chave: Terminologia; Lexicografia Especializada; Corpus; Validação; Aviação; Meteorologia Aeronáutica

TradTerm, São Paulo, v.37, n. 1, janeiro/2021, p. 175-204

Número Especial - Linguística de Corpus www.revistas.usp.br/tradterm 


\section{Introduction}

The resource of a corpus may be used in several fields in linguistics - as a broader area; to more specific fields such as natural language processing for research in electronic lexicography, general-purpose speech ${ }^{1}$-, and terminology $^{2}$ - for specialized speech, among others. For each field, or research objective, the use of corpora differs according to the parameters set for the specific research.

For example, in lexicographic or terminological studies, it is important to have a somewhat freer approach, to enable better systematization and more comprehensive understanding of meaning, while in a grammatical approach it is relevant to have an annotated corpus, to enable a more specific syntax analysis. On the other hand, data provided are more objective for the lexicographer or terminologist, whereas a grammarian is likely to have to formulate more hypotheses regarding formal and functional relations between words.

Within this context, the support of authentic texts has been largely used mainly in historical approaches to language, but only as a means to find evidence for an already set theoretical foundation, based on intuition. This way of doing research was later formalized as a 'corpus-based perspective' or, as Tognini-Bonelli (2001) points out, "a pre-corpus perspective". Later, along with technological advances, it was possible to compile large amounts of discourse, enabling better systematization from the corpus evidence itself, a perspective named 'corpus-driven'.

This idea of systematization takes into account what a given pattern of language use means, and how it can be evaluated in terms of typicity in a

\footnotetext{
${ }^{1}$ Speech is being used here in a broad sense, to refer to written and spoken expressions of language.

2 The boundary between some of these areas may be very subtle. In the case of 'terminology', for example, it may also be called 'specialized lexicography'. In the same way, 'electronic lexicography' could also be called 'computational linguistics', as emphasizing the support of computer applications and other computational resources to process language, mainly in the field of natural language processing (NLP). However, in spite of the fact methodological procedures may be shared by these fields, as using computer tools is currently deemed as a sine-qua-non condition of sophisticated language research, there still remains, of course, fundamental theoretical distinctions regarding research concerning words in a general context and terms in specialized fields.
}

TradTerm, São Paulo, v.37, n. 1, janeiro/2021, p. 175-204 Número Especial - Linguística de Corpus www.revistas.usp.br/tradterm 
given system. In other words, language features have to be understood as the probability of occurring in a general context or in a certain domain, not as a "fatalistic" evaluation of occurrences, of happening vs. not happening at all. As Tognini-Bonelli (2011: 57) points out, "presence or absence is one thing, but frequency is another", which prompts the understanding of making efforts on how to analyze language patterns in a more contextualized way, also taking into consideration how a given corpus is compiled.

When it comes to specialized fields, establishing a normalized terminology is one of the most relevant elements to ensure information is being disseminated as most accurately as possible. In this sense, in the field of aviation, a safety-critical environment, the broad use of corpora may pose very positive influence to best relate normative and descriptive use of language, especially in the Aeronautical Meteorology subfield, which also comprises possible other classifications of a term within the same field ( $\mathrm{Cf}$. PEIXOTO 2020b, in press).

By taking these assumptions into consideration, based on terminology (Pavel; Nolet 2001; Cabré 1999 and 2003) and corpora (SAntos 2008 and 2014; TOGNINI-BONELLI 2011) theoretical frameworks, this paper aims at discussing definitions and translation to Portuguese of expressions and terms contained in Table 4678, concerning the main aeronautical meteorology codes, in order to highlight nuances of meaning which could interfere in proper communication of content.

This mentioned table is relevant because it is used as a reference in the Aeronautical Meteorology field, as prescribed by the World Meteorological Organization (2011). As detailed later in this paper, Table 4678 is organized in two parts - qualifiers and the phenomenon itself -, so as to combine different aspects of a given weather phenomenon, represented by letter codes with or without a positive or negative sign.

The proposed analysis is based on a systematization for terminological procedures, by using corpora with set validation standards, since the discussions around corpora have reached more sophisticated levels, especially in terms of how computer tools may help the terminologist to process large amounts of specialized discourse.

TradTerm, São Paulo, v.37, n. 1, janeiro/2021, p. 175-204 Número Especial - Linguística de Corpus www.revistas.usp.br/tradterm 
However, this paper follows the approach that corpora must be used as a process of systematization, to help the researcher with weighing options regarding validation. It is not a strict process of quantification, whether established prior to or later in the elaboration of a terminological database, but a process of evaluating how relevant the corpus is and, especially, how to set specific parameters for each intended use.

For that, as the compiled Aeronautical Meteorology corpora is still under development, the parameters for the validation process were applied "manually", and are intended to contribute to avoid misunderstandings regarding the criticality level of meteorological situations being communicated during air traffic operations.

\section{Terminology and specialized translation}

In 1972, Terminology was established as a field of study, following the ideas disseminated by Eugen Wüster, who idealized the General Theory of Terminology (GTT), according to which terms were considered to express concepts $^{3}$ (and not meanings).

After this pioneering moment of Terminology studies, a functionalist perspective of language started to be more disseminated, comprising a more descriptive approach to the specialized lexicon. This tendency was also followed by the Canadian School (Cf. PAVEL; Nolet 2001) and by the Catalan María Teresa Cabré, who proposed the Communicative Theory of Terminology (CTT).

For Cabré (1999 and 2003), the meaning of the term is relative, as it depends on its communicative scenario ${ }^{4}$ and, within the scope of specialized communication, it may acquire terminological status. In other words, a same given word considered to belong to the general lexicon may also be considered a term, as long as, in a given specialized segment, it has a well-defined sense.

\footnotetext{
${ }^{3}$ For Wüster, scientific concepts are atemporal, paradigmatic and universal, while meanings are linguistic and variable (Cf. KRIEGER; FINATTO 2004: 33).

${ }^{4}$ A communicative scenario may be understood as a discursive universe. For Cabré (1999 and 2003), a 'communicative scenario' is a concept of pragmatic nature, which considers the language in use; a 'discursive universe', referring to the text typologies (scientific, legal, political, etc), which have specific objectives and structures.
}

TradTerm, São Paulo, v.37, n. 1, janeiro/2021, p. 175-204

Número Especial - Linguística de Corpus

www.revistas.usp.br/tradterm 
It is also interesting to note that, even in a same contextualized specialized field, such as aviation, where standardization is critically paramount, there are cases of terms which might have a different meaning based on localization criteria, i.e. different locations with language variations as in Brazil and Portugal ${ }^{5}$.

For example, in his research, Rabello (2011: 45) stated the difference in meaning for the term 'arremeter', in Portuguese:

in Brazil the term Arremeter means interrupting a process of landing and climbing again, immediately. On the other side, in Portugal, the same term means forcing to land, in any way. ${ }^{6}$ (RABELLO 2011: 45)

As an analogy, in English, 'arremeter' may be equivalent to 'go-around' and 'missed approach', with some nuances: while 'go around' is generally an instruction by an air traffic controller and may also lead to another attempt to land, 'missed approach' is an aborted landing maneuver carried out due to technical issues.

These differences corroborate the fact that the process of translation is not an end in itself, but presupposes a situated activity, in which there will be correspondence of data, whether corpora or terms, by a specific culture or a given technical field (Cf. KRIEGER; FINATTO 2004). The translation process is, therefore, a form of rewriting, in which ideological and/or sociological factors are also determined by the dissemination of the same idea in the target language, even in the case of specialized translation.

Nonetheless, as mentioned by Krieger and Finatto (2004), 'specialized language'7, as it was called in the 18th Century, used to be seen as in vitro and static, and for some time has been considered in vivo and adaptable to the communicative moment. As a result, the traditional approach of designing

\footnotetext{
${ }^{5}$ In their research on culinary texts, Tagnin and Teixeira (2004) found differences between Brazilian Portuguese and European Portuguese are much more marked than differences between American English and British English.

6 "no Brasil, o termo Arremeter significa interromper o processo de pouso e subir novamente, imediatamente. Por outro lado, em Portugal, o mesmo termo significa forçar o pouso, de qualquer maneira" (RABELLO 2001: 45, original). All translations by the author of this paper, unless otherwise noted.

${ }^{7}$ For Hurtado Albir (2001: 59 apud KRIEGER; FINATTO 2004: 66), all translations are specialized, even those which are not considered to be in the technical and scientific field. Therefore, the expression 'translation of specialized texts' must be used instead of 'specialized translation'.
}

TradTerm, São Paulo, v.37, n. 1, janeiro/2021, p. 175-204

Número Especial - Linguística de Corpus www.revistas.usp.br/tradterm 
policies and standards for specialized terminology led to the institution of the study objects, in Terminology, term, phraseology and definition.

For the analysis of such study objects, the most important ability for the terminologist is being a high-skilled researcher, and not necessarily having full understanding of the field, as a specialist (THELEN 2015; TAGNIN 2013). In that, the expertise of the terminologist is key for the quality of this work, since (s)he is a trained professional for managing language resources in a more comprehensive way, to search, investigate and evaluate relevant sources, in any field. Specialists on the other hand play the role of resourceful partners able to clarify very specific issues. As stated by Thelen (2015: 373), "for translators it suffices that they know the language of a subject field, and that they know to find their way in the field; they need not be specialists". Taking this into account, the following topic addresses an expanded discussion regarding terminology objects.

\section{Term definition}

Along with the CTT perspective (CABRÉ, 1999 and 2003), the term is considered to have a polyhedric structure, comprising its linguistic, cognitive and sociocultural nature. Phraseology refers to nominal and verbal syntagmas, as idiomatic expressions, sayings and proverbs; and the definition is a description based on the presence or absence of semic traces, as opposing genus $(G)$ and differentia $(D)^{8}$. For example, an 'airplane' would be a means of transportation (G) designed to travel through air (D).

In this way, a series of semic traces may be listed, and the absence or presence of those semic traces will define the specialized sense. For example, in a sort of binary polarization, the same word 'airplane' may be classified regarding categories of means of transportation(+), ground(-), motorized(+),

\footnotetext{
${ }^{8}$ As based on the Aristotelian assumption of term definition (term = genus + differentia), genus refers to a general class or category, and differentia is a particular aspect which distinguishes one term from other terms. Although this was originated from a stricter perspective on Terminology (GTT), it is still fundamental to the structuring of definitions in more functionalist approaches, such as the CTT. Some parameters to formulate specialized definitions in the Aeronautical Meteorology domain is more broadly discussed in Peixoto (2020a, in press).
}

TradTerm, São Paulo, v.37, n. 1, janeiro/2021, p. 175-204

Número Especial - Linguística de Corpus www.revistas.usp.br/tradterm 
piloted $(+ \text { ou }-)^{9}$, etc. This classification would be more objective when trying to automate the definition or term equivalence work, for use in computational applications (Cf. SAGER; L'HOMME 1994).

Within this scope, defining a term is crucial for the development of terminological and terminographical work. According to Krieger and Finatto (2004), a term is a complex unit "whose recognition is based on one of the hardest tasks of a terminological work." 10 (2004: 76). For Pavel and Nolet (2001), a term may be

a word, a syntagma, a symbol, a chemical or mathematical formula, a scientific name in Latin, an acronym, an abbreviation or the denomination or the official title of a position, organization or administrative entity (PAVEL; Nolet 2001: 18-9).

In a broader sense, Krieger and Finatto (2004: 77) consider terms to be lexical entities which may express concepts, objects or processes. In this way, as also defended by Cabré (1999 and 2003), such lexical entities could also be common words which may have undergone a terminologization process

by which words of the common language are resignified, and reach the status of a term. In this process, common words acquire specialized meanings, which belong to a certain field of scientific or technical knowledge, and become, therefore, elements comprised by the repertoire of terms ${ }^{11}$ (KRIEGER; FINATTO 2004: 79).

In this way, it is a fact that the classification as a term is not necessarily derived from the identification of morphosyntactic components, once it is not a case of structural equivalence (Cf. TOGNINI-BONELLI, 2001), but definition of specialized senses, as in the case of 'holding point', directly translated to Portuguese as 'ponto de espera', and 'grip tester', adapted to Portuguese as 'equipamento medidor de atrito', both considered terms.

The compilation of term definitions for the elaboration of terminological products such as glossaries, dictionaries, databases and automated systems for

9 The traditional airplane has a human pilot, but it also has an autopilot function for cruise flight, to keep constant altitude and speed. Nowadays, airplane models (without transportation of passengers), the so-called Unmanned Air Vehicles (VANT), have become increasingly more popular.

10 "cujo reconhecimento consiste numa das mais difíceis tarefas do trabalho terminológico" (KRIEGER; FINATTO 2004: 76, original).

11 "por meio do qual palavras da língua comum sofrem uma ressignificação, passando a alcançar estatuto de termo. Nessa passagem, palavras comuns adquirem significados especializados, pertinentes a determinado campo de saber científico ou técnico, tornando-se, então, elementos integrantes de repertórios de termos" (KRIEGER; FINATTO 2004: 79, original).

TradTerm, São Paulo, v.37, n. 1, janeiro/2021, p. 175-204 Número Especial - Linguística de Corpus www.revistas.usp.br/tradterm 
terminology recognition is an essential task mainly for Terminography, an applied application of Terminology.

On this issue, as a support for the extraction of terms and building of terminological products, Electronic Lexicography has been standing out, as an applied area which deals with management of terms, whether or not specialized, in a computational environment. This area is currently one of the most fruitful environments to seek for methodological renovations, since it makes broader use of corpora and other technological resources which are very productive for the management of terminology ${ }^{12}$, as discussed in the following topic.

\section{Corpus research: an approach to systematization}

The use of corpora and lexicographical tools has several applications both for linguistic and computational purposes. In the field of aviation, corpora have been more broadly used in this past decade, as shown in the works by TosquiLucks (2018), Prado (2018), Prado (2015), Rabello (2011), Gonçalves (2017), Lepri (2017), Prado and Tosqui-Lucks (2019), Prado and Tosqui-Lucks (2017) and Prado (2010).

There has been an exponential improvement of corpora resources since the first ones were developed. At the outset, electronic corpora used to have about 1 million words, such as the one created by the Brown University in 1967, then computational advances allowed words to be added to online databases to a greater extent: the Birmingham University developed a corpus with 10 million words in 1987; the British National Corpus was created with 100 million words in 1994; and nowadays corpora commonly have a quantity of words in the order of billions (Cf. LEW 2009).

As a result, there have been significant changes in theoretical perspectives, as Tognini-Bonelli (2001) describes: from corpus-based approaches to corpus-driven approaches. Still today, new insights are triggered based on

\footnotetext{
12 Terminology is regarded as a domain knowledge by many NLP or text analytics applications in order to process unstructured information in specialized fields, to design termbases.
}

TradTerm, São Paulo, v.37, n. 1, janeiro/2021, p. 175-204 Número Especial - Linguística de Corpus www.revistas.usp.br/tradterm 
more and more specialized target audiences, which now also include professional linguists, translation specialists and specialists from other fields.

Although these two approaches seem to be compared in a more dichotomic way, they are actually part of a continuum of linguistic possibilities of analysis, as mentioned in the introduction of this paper. In other words, the corpus-based approach was not limited in its conceptualization but had the purpose of making best use of corpora available at the time, which were much smaller. Therefore, it was not possible to define language patterns, since representativeness was a major issue: it was more common to use only text samples, not full texts. When computational tools became more available, language processing developed into so many possibilities, also based on statistical analysis, and it was possible to refine the so-called corpus driven methodology (Cf. TogNINI-BonelLI, 2001; KILGARRIFF, 1997), and focus on systematization taking into consideration the compilation process (SANTOS 2008).

In this perspective, it was possible to relate corpora and tools in several scopes of activity, and potentialize the linguistic analysis in several study areas, among which translation. However, as mentioned by Anthony (2013), it is important to highlight that corpora are linguistic data that need suitable analytical tools. Since different tools result in different analyses of the same data $\operatorname{set}^{13}$, adequate utilization of corpus data is directly related to the tools used and understanding how they works (Cf. Hunston 2002).

Therefore, it is of paramount importance to delimitate definitions for each element (word, etc), according to a given theoretical model, as divergence regarding some definitions could result in different statistical numbers (ANTHONY 2013), mostly due to frequency issues, as explained in the following topic.

\section{Terminological validation process: frequency issues of corpus research}

The validation process of terminological work is one of the most important aspects of such work, especially when considering sensitive areas,

\footnotetext{
${ }^{13}$ Anthony (2013) makes an analogy with procedures in the field of Astronomy, in which the detailed data evaluation will depend on the tools used for observation.
}

TradTerm, São Paulo, v.37, n. 1, janeiro/2021, p. 175-204

Número Especial - Linguística de Corpus

www.revistas.usp.br/tradterm 
as in the case of aviation. In this way, the productivity of corpus research, when it comes to such a validation process of terminology data, is directly related to frequency issues.

At first, it is necessary to highlight that a high number of occurrences does not necessarily mean a high level of terminological expressiveness. Although the well-known statistical logic indicates that "big data is good data", the occurrence (or not) in a corpus may not be considered irrefutable evidence because the value or validity of a corpus is not restricted to the size of the corpus, but to the purpose and type of information which may be extracted from it.

As theorized by Zipf (SANTOS 2008; MANNING; SCHÜTZE 1999; LeW 2009), sometimes a higher number of occurrences only represent connecting elements or other featureless words, intrinsically more common in a language, while a lower frequency may make evident a term with a relevant terminological semantic load. As a result, the absolute frequency is not necessarily the most important or the most productive; in fact, "Zipf's law is a power law stating that the frequency of any word is inversely proportional to its rank" (PUSTEJOVSKY; STUBBS 2013: 66). It is related to the occurrence of hapax legomena, i.e. the single occurrence of an ordinary word in a given corpus.

Santos (2008) agrees with this point of view and states that the representativeness of a corpus is the "information (...) on the relative weight of a given question regarding the represented universe" 14 (SANTOS 2008: 54). In a language, it is shown that several different cases (in theory, non-normative) always occur in a low frequency while few cases occur in a high frequency.

Under this scope, it is possible to understand that, in linguistics with corpus (SANTOS 2008 and 2014), systematization nuances are actually a criterium of analysis, and definitions of algorithms have to be clearly explained. An example of how this could pose obstacles to the productivity of a tool is the case of WebAnno, which, although pointing out the statistical method of kappa (CARLETTA 1996), does not distinguish some indicators in a clear way, making the suitable interpretation of results obtained impossible.

\footnotetext{
14 “informação (...) do peso relativo de uma dada questão em relação ao universo representado" (SANTOS 2008: 54, original).
}

TradTerm, São Paulo, v.37, n. 1, janeiro/2021, p. 175-204

Número Especial - Linguística de Corpus

www.revistas.usp.br/tradterm 
When corroborating this relation between linguistics and systematization enabled by suitable statistics, Santos (2014) mentions, following Guiraud (1960), that linguistics is a statistical science par excellence (SANTOS 2014: 197), as it is not possible to dissociate quantitative and qualitative natures. As stated by Santos (2014):

to count, it is necessary to categorize, and when categorizing we find out grammar features in a language that we would never have stumbled upon without this effort for systematization ${ }^{15}$ (SANTOS 2014: 210).

Therefore, although linguistics with corpus is mostly qualitative, there are also empirical studies using corpora, which may be exploratory or experimental. In the first case, there may be a collection of samples and some data are identified, such as "there are more verbs $X$ than verbs $Y$ ", whereas, in the second case, there is a given hypothesis ("language favours the abstract expression").

In the case of terminology work, as discussed by Thelen (2015) when comparing a theory-oriented terminology vs. a translation-oriented terminology, a theory-oriented approach will help the terminologist to define his/her strategy, instead of using only a translation-approach, mostly based on practice.

It is also important to have a high standard when compiling texts which may be relevant for a specific field, in order to organize the corpus in a more specific or more balanced way, to avoid bias. This is not an easy task, not just because it requires strategical planning but also due to the fact more practical computational issues may arise when dealing with the compiled data, as discussed in the following item.

\section{Methodology}

The methodology of this research was based on a systematization by using corpus, to set validation standards for the proposed analysis, considering both

\footnotetext{
15 "para contar, é preciso categorizar, e ao categorizar descobrimos qualidades da gramática de uma língua com que nunca teríamos deparado sem esse esforço de sistematização" (SANTOS 2014: 210, original).
}

TradTerm, São Paulo, v.37, n. 1, janeiro/2021, p. 175-204

Número Especial - Linguística de Corpus www.revistas.usp.br/tradterm 
quantitative and qualitative parameters, i.e. corpus-based and corpus-driven premises for this intended objective (Cf. SANTOS 2008).

Generally speaking, the basic distinction between the two approaches relies on the theoretical perspective adopted: having a previous assumption to be confirmed by corpus evidence or carrying out a freer analysis to find language patterns, i.e. create categories.

For this reason, annotation or tags serve different purposes, depending on the intended use. Since the corpus-driven approach has a more specific stance, it does not use annotation, as there could be bias in data analysis, contaminating them. In the case of a corpus-based approach, annotation or tags are considered necessary to test a given linguistic theory. Current tools provide layers of data in different formats, in a way annotation or tags may be deactivated at the researcher's discretion, to show the original text again, for a freer analysis.

Within this context, corpus linguistics derived from the first approach of corpus-based research, considered a kind of tool, complementary to language studies. Then, corpus-driven approach established itself as a very robust field of study heavily relying on statistics.

Santos (2008) offers a more flexible standpoint, taking into consideration both perspectives of corpus-based and corpus-driven, according to the needs of a particular object of study. This approach was named "Linguistics with Corpus" (or linguistics supported by corpora), and focused on the compilation process. As a result, Santos (2008) defended that "a corpus is a collection of classified linguistic objects to be used in the Natural Language Processing / Computational Linguistics / Linguistics fields" 16 (SANTOS 2008: 45), created for specific purposes, to assist in the linguistic study, and analysis of occurrence of words and syntactical structures, among other structures, which may be counted and categorized, but not in a very strict methodological pattern.

Based on this theoretical stance, this paper aims at analyzing the weather phenomena specified in Table 4678 (WMO, 2011), a reference in the Aeronautical Meteorology field, by investigating meanings and nuances found in the compiled corpus, in order to discuss and validate the nomenclatures in Portuguese.

16 "um corpo é uma coleção classificada de objetos linguísticos para uso em Processamento de Linguagem Natural / Linguística Computacional / Linguística” (SANTOS 2008: 45, original).

TradTerm, São Paulo, v.37, n. 1, janeiro/2021, p. 175-204 Número Especial - Linguística de Corpus www.revistas.usp.br/tradterm 
To this end, publications from six categories were selected for the Aeronautical Meteorology (AER MET) corpus, taking into consideration that AER MET publications are much scarcer than general aviation ones, especially in the case of Portuguese documents. As a result, it was possible to find many institutional publications in English, whereas in Portuguese it was necessary to search for more academic studies, in order to comprise a broader range for the AER MET field. Therefore, the English and Portuguese subcorpora were balanced differently.

The corpus architecture of this research comprised the following categories: (a) terminological databases; (b) institutional publications; (c) commercial documents; (d) institutional didactic instructions; (e) academic publications; and (f) publicity documents, as shown in the following table:

Table 1. Corpus Architecture. CAT - category; Nr. PT - number of publications in Portuguese; Nr. EN - number of publications in English.

\begin{tabular}{|c|c|c|c|}
\hline CAT & Description & Nr. PT & Nr. EN \\
\hline $\begin{array}{l}\text { terminological } \\
\text { databases }\end{array}$ & $\begin{array}{l}\text { glossaries and dictionaries } \\
\text { (print, online or in .pdf) }\end{array}$ & 5 & 7 \\
\hline $\begin{array}{l}\text { institutional } \\
\text { publications }\end{array}$ & regulations and technical reports & 52 & 62 \\
\hline $\begin{array}{l}\text { commercial } \\
\text { documents }\end{array}$ & $\begin{array}{l}\text { documents from companies selling } \\
\text { meteorological instruments }\end{array}$ & 0 & 75 \\
\hline $\begin{array}{l}\text { institutional } \\
\text { didactic } \\
\text { instructions }\end{array}$ & $\begin{array}{l}\text { training material published by } \\
\text { institutional organizations and } \\
\text { publications for proficiency purposes }\end{array}$ & 1 & 4 \\
\hline $\begin{array}{l}\text { academic } \\
\text { publications }\end{array}$ & theses, dissertations and books & 361 & 40 \\
\hline $\begin{array}{l}\text { publicity } \\
\text { documents }\end{array}$ & $\begin{array}{l}\text { journals for general dissemination of } \\
\text { information }\end{array}$ & 0 & 1 \\
\hline TOTAL & & 419 & 189 \\
\hline
\end{tabular}

Source: Author (2020)

After the compilation of .pdf files, they were converted into .txt, to enable better search, primarily using the AntConc suite. However, file conversion itself posed some issues as some documents, especially the academic ones, showed some OCR errors or could not be converted at all. In 
those cases, some different online converting tools were tested for each file and it was possible to eventually convert most publications ${ }^{17}$.

However, since compilation of this Aeronautical Meteorology corpus is still ongoing, more data will be compiled and duly organized according to set validation standards proposed in this paper. Therefore, each category of the corpus architecture will have a different weight regarding its "level of authoritativeness", depending on the purpose of the research. In this way, this Aeronautical Meteorology corpus intends to acknowledge a more comprehensive scope of specialized sources while emphasizing the higher relevance of a given category for a given purpose.

In the case of this research, although the aim is analyzing terminology used by official institutions, language used by the professional community in other institutions and companies were also taken into account, as they rely on official guidelines. For this paper, because the corpus is still under development, the validation standard was applied "manually".

In order to provide better familiarization with the AER MET area and specificities of publications in this field, the following sections will provide some explanation regarding the main AER MET institutions, then the code nomenclatures will be discussed.

\section{The Aeronautical Meteorology field}

In terms of worldwide institutional guidelines, the Aeronautical Meteorology field follows standards and recommendations prescribed by the World Meteorological Organization (WMO) and the International Civil Aviation Organization (ICAO). In the case of the WMO, founded in 1919, it has a specialized group for Aeronautical Meteorology, named Commission for Aeronautical Meteorology (CAeM), which was formerly named Commission for the Application of Meteorology to Air Navigation (CAMAN). As explained in the Aeronautical Meteorology Programme Homepage, in the WMO website:

The first ancestor of the current CAeM was the Commission for the

Application of Meteorology to Air Navigation (CAMAN) established

\footnotetext{
${ }^{17}$ As this AER MET corpus is an ongoing project, those issues are to be resolved during the corpus expansion.
}

TradTerm, São Paulo, v.37, n. 1, janeiro/2021, p. 175-204

Número Especial - Linguística de Corpus

www.revistas.usp.br/tradterm 
by the Paris Conference of Directors (CD) of the International Meteorological Organization (IMO) as early as 1919. The rapid development of the civil aviation after the end of the World War I required development of internationally agreed methods and procedures to address the needs of the aviation for meteorological data and information. It should be noted that already in 1920 regular air services were established between London, Paris, Brussels and Amsterdam (WMO 20-?, emphasis in original).

The formal interrelation between the ICAO, founded in 1947, and the $W_{M O}{ }^{18}$ was first introduced by Doc 7475 , edited in 1963, where it is defined as a "formal interagency agreement" (ICAO 1963, Foreword), with working arrangements approved in 1953 by both organizations, to be effective as of 1 January 1954.

The purpose of this arrangement was establishing a delimited scope of work for each organization, in a way to employ resources more effectively, as stated in Doc 7475 (ICAO 1963):

these arrangements are designed to record the understanding reached between the two Organizations to delineate their respective spheres of activity in the field of aeronautical meteorology, to provide machinery for their collaboration when necessary and to give guidance for the conduct of meetings of representative bodies and the Secretariats of the two Organizations and thus to assist in the realization of the aims outlined in the preamble to this document (ICAO 1963, Foreword).

Along with this purpose of interaction, it was established the ICAO would be in charge of "defining and encouraging the provision of services" (ICAO 1963: 3), whereas the WMO would be responsible for "specifying the technical methods and practices recommended for use in providing required meteorological services" (ibidem), as well as promoting scientific research in the Aeronautical Meteorology field. However, this classification of activities would not necessarily be clear cut, since both organizations could actually work jointly to solve an issue of shared interest, and also resort to other institutions.

18 Both the World Meteorological Organization (WMO) and the American Meteorological Society (AMS), in the United States, were founded in the same year, 1919, much before the foundation of the UN (1945) and its specialized agency ICAO (1947). Within this scope of postwar development, regarding World War I, the WMO and the AMS had the purpose of incentivizing scientific research in the field of Aeronautical Meteorology.

TradTerm, São Paulo, v.37, n. 1, janeiro/2021, p. 175-204 Número Especial - Linguística de Corpus www.revistas.usp.br/tradterm 
As a result, States currently follow WMO standards for methodological actions, including use of terminology, whereas the ICAO is the reference institution for recommended services, in alignment with other countries. It is important to emphasize, though, that the rules prescribed by the ICAO are classified as standard and recommended practices and procedures, where 'standard' refers to actions which shall be taken by States and 'recommended' refers to actions which should be taken by States.

In Brazil, the Department of Airspace Control (DECEA) is the official regulating agency for the Aeronautical Meteorology field and it issues publications according to actions prescribed by the ICAO, along with the WMO standardized methodology. More recently, precisely on March 26, 2020, a new center named Integrated Center of Aeronautical Meteorology (CIMAER) was inaugurated at the Galeão Airport (SBGL) in Rio de Janeiro, with the purpose of centralizing all Air Force units working in this field. With this new configuration, it is important to make efforts to try to ease Aeronautical Meteorology communication, shedding light on specific differences in key terms regarding weather phenomena, especially the ones used in the Aeronautical Meteorology Codes Table, as discussed in the next topic.

\section{Terminology of Aeronautical Meteorology codes: contribution from corpus analysis}

As stated before, the field of Aeronautical Meteorology is very specific and there are not as many publications available as in general aviation. Within this context, it is important to highlight that Aeronautical Meteorology terms may be used in a different way when it comes to the general use of terms in the field and the codes themselves, as prescribed by the WMO, in English; and in the DECEA publications, in Brazilian Portuguese.

The detailed way those Codes are to be used in Aeronautical Meteorology is explained in Doc 782, edited in 2019, a user's guide on how codes should be used, in which situations and how the format should be.

TradTerm, São Paulo, v.37, n. 1, janeiro/2021, p. 175-204 Número Especial - Linguística de Corpus www.revistas.usp.br/tradterm 
Other publications, both from the ICAO and the WMO, also show complementary information on those procedural guidelines.

To allow better visualization, information from tables 4677 and 4678 from the WMO (2011) and Brazil (2017a) were organized in Figure 1 and Figure 2, in order to focus on the codes and the nomenclatures, respectively.

Figure 1. Table 4678 - codes for weather phenomena (WMO)

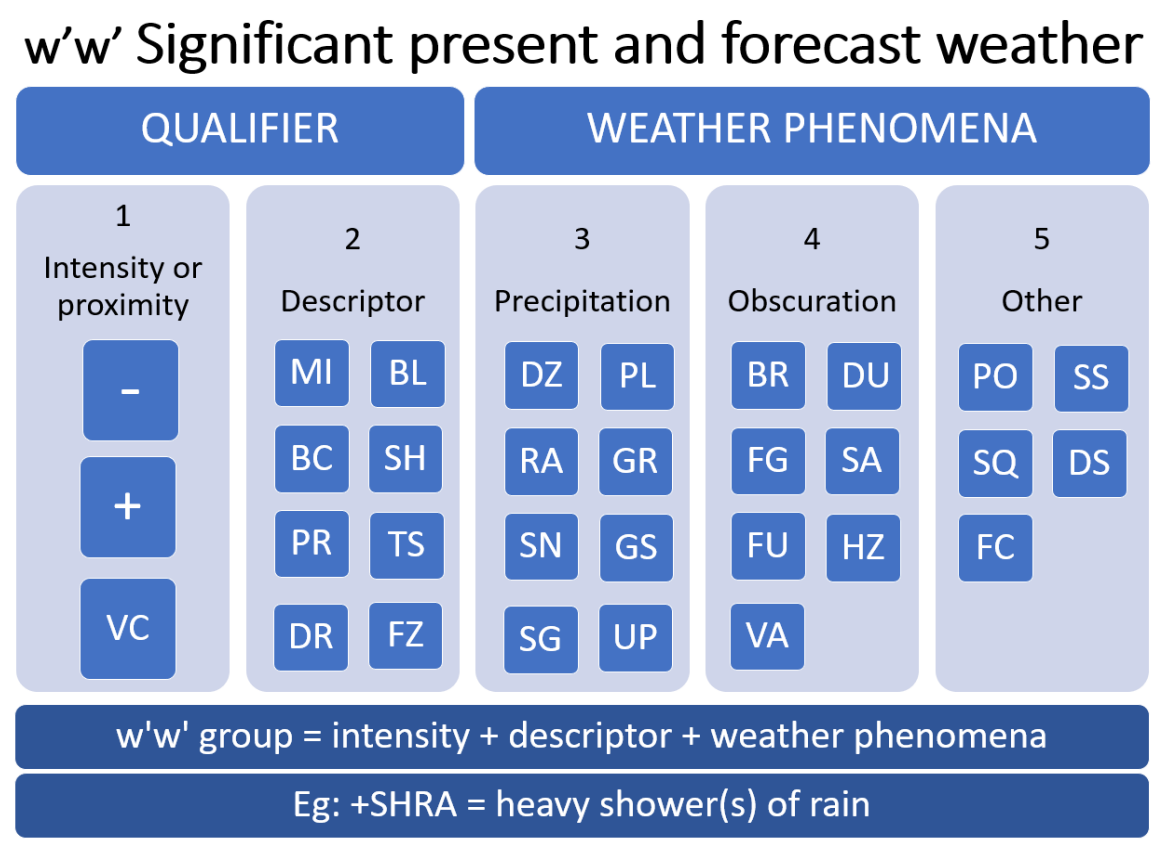

Source: Adapted from WMO (2011)

The nomenclature of each code shown in Figure 1 is specified in Figure 2, in English and in Portuguese, as follows:

TradTerm, São Paulo, v.37, n. 1, janeiro/2021, p. 175-204

Número Especial - Linguística de Corpus www.revistas.usp.br/tradterm 
Figure 2. Code nomenclatures in English and in Portuguese

\begin{tabular}{|c|c|c|}
\hline Code & Nomenclature in English & Nomenclature in Portuguese \\
\hline \multirow[t]{2}{*}{-} & Light & Leve \\
\hline & Moderate (no qualifier) & Moderada (sem sinal) \\
\hline+ & $\begin{array}{l}\text { Heavy: well developed in the } \\
\text { case of dust/sand whirls (dust } \\
\text { devils) and funnel clouds }\end{array}$ & $\begin{array}{l}\text { Forte (bem desenvolvido para } \\
\text { redemoinhos de poeira/areia e } \\
\text { nuvens funil) }\end{array}$ \\
\hline VC & In the vicinity & Na vizinhança \\
\hline MI & Shallow & Baixo \\
\hline$B C$ & Patches & Bancos \\
\hline PR & $\begin{array}{l}\text { Partial (covering part } \\
\text { of the aerodrome) } \\
\end{array}$ & $\begin{array}{l}\text { Parcial (cobrindo parte } \\
\text { do aeródromo) }\end{array}$ \\
\hline DR & Low drifting & Flutuante baixo \\
\hline $\mathrm{BL}$ & Blowing & Soprada \\
\hline SH & Shower(s) & Pancada(s) \\
\hline TS & Thunderstorm & Trovoada \\
\hline $\mathrm{FZ}$ & Freezing (supercooled) & Congelante \\
\hline DZ & Drizzle & Chuvisco \\
\hline RA & Rain & Chuva \\
\hline SN & Snow & Neve \\
\hline SG & Snow grains & Grãos de neve \\
\hline PL & Ice pellets & Pelotas de gelo \\
\hline GR & Hail & Granizo \\
\hline GS & $\begin{array}{c}\text { Small hail and/or snow } \\
\text { pellets }\end{array}$ & $\begin{array}{c}\text { Granizo pequeno e/ou } \\
\text { pelotas de neve }\end{array}$ \\
\hline UP & Unknown precipitation & $\begin{array}{l}\text { [no translation in Table } 4678 \\
\text { published in ICA 105-16 } \\
\text { (BRAZIL, 2017a)] }\end{array}$ \\
\hline BR & Mist & Névoa úmida \\
\hline FG & Fog & Nevoeiro \\
\hline FU & Smoke & Fumaça \\
\hline VA & Volcanic ash & Cinzas vulcânicas \\
\hline DU & Widespread dust & Poeira em área extensa \\
\hline SA & Sand & Areia \\
\hline $\mathrm{HZ}$ & Haze & Névoa seca \\
\hline PO & $\begin{array}{l}\text { Dust/sand whirls } \\
\text { (dust devils) }\end{array}$ & $\begin{array}{l}\text { Poeira/areia em } \\
\text { redemoinhos }\end{array}$ \\
\hline SQ & Squalls & Tempestades \\
\hline $\mathrm{FC}$ & $\begin{array}{l}\text { Funnel cloud(s): tornado or } \\
\text { waterspout }\end{array}$ & $\begin{array}{l}\text { Nuvem(ns) funil: tornado ou } \\
\text { tromba d'água }\end{array}$ \\
\hline SS & Sandstorm & Tempestade de areia \\
\hline DS & Duststorm & Tempestade de poeira \\
\hline
\end{tabular}

Source: Adapted from WMO (2011) and BRAZIL (2017a).

TradTerm, São Paulo, v.37, n. 1, janeiro/2021, p. 175-204 Número Especial - Linguística de Corpus www.revistas.usp.br/tradterm 
Because the meaning of terms regarding weather phenomena is very specific, it is important to analyze its use in order to best understand nuances and avoid miscommunication when reporting a weather issue.

Some of the major aspects of Aeronautical Meteorology nomenclatures are the nuances regarding fog, mist and haze, and the precipitation scale to define intensity of weather phenomena. Since these phenomena pose a real impact on visibility, they are deemed very hazardous to aircraft operations (Cf. GULTEPE 2009).

Regarding 'fog' (FG), 'haze' (HZ) and 'mist' (BR), the classification depends on humidity and visibility issues. 'Fog' is reported when the air is at about 100 per cent humidity and the visibility is less than $1000 \mathrm{~m}$ (Cf. ICAO 2005), while 'mist' presents visibility ranging from $1000 \mathrm{~m}$ and 5000 $\mathrm{m}$, and relative humidity above 90 per cent. (Cf. ICAO 2005). On the other side, 'haze' are "extremely small particles invisible to the naked eye and sufficiently numerous to give the air an opalescent appearance [...], usually only a few thousand feet thick, but may extend upwards to 15,000 feet $(4,600$ meters) [...]" and visibility may vary "greatly, depending on whether the pilot is facing into or away from the sun" (FAA 2016: 16-5). Concerning these terms, although "mist may be considered an intermediate between fog and haze" (ibidem), identifying these phenomena may be critical, as "there is no distinct line between any of the categories" (ibidem). In Portuguese, fog (FG), haze $(\mathrm{HZ})$ and mist (BR) are translated as 'nevoeiro', 'névoa seca' and 'névoa úmida', respectively.

The occurrence of fog, haze and mist may be full or localized (in patches or bank), especially regarding 'fog'. While the nomenclature specifies patch(es) (BC) as the descriptor, to be used in a structure like 'patch(es) of ', , this word is used in the AER MET literature in a more general sense, with other sorts of combinations, such as 'patches of blue sky', 'patches of cloud', 'patches of convection', 'patches of light', 'patches of anomalous structure', 'patches of dry snow', 'patches of foam', 'patches of greater or lesser development [such as clusters of apartments, shops, factories or parks, open areas or water]', patch(es) of ground, and 'patches of heavy rain'.

TradTerm, São Paulo, v.37, n. 1, janeiro/2021, p. 175-204 Número Especial - Linguística de Corpus www.revistas.usp.br/tradterm 
As qualifiers used before the noun 'patch(es)', words such as 'snow', 'ice', 'wet', 'water, 'grease' are largely used, as well as 'great', 'large', 'small' and 'circular'. In addition to that, 'patch' itself in a qualifier form ('patchy') was also found in the corpus, with a varied range of collocates, as 'patchy band of convective cloud', 'patchy cloud', 'patchy fog', 'patchy grey', 'patchy ground', 'patchy ice', and 'patchy troposphere', as illustrated in Figure 3 below:

Figure 3 - Occurrences of 'patchy' in the Aeronautical Meteorology Corpus

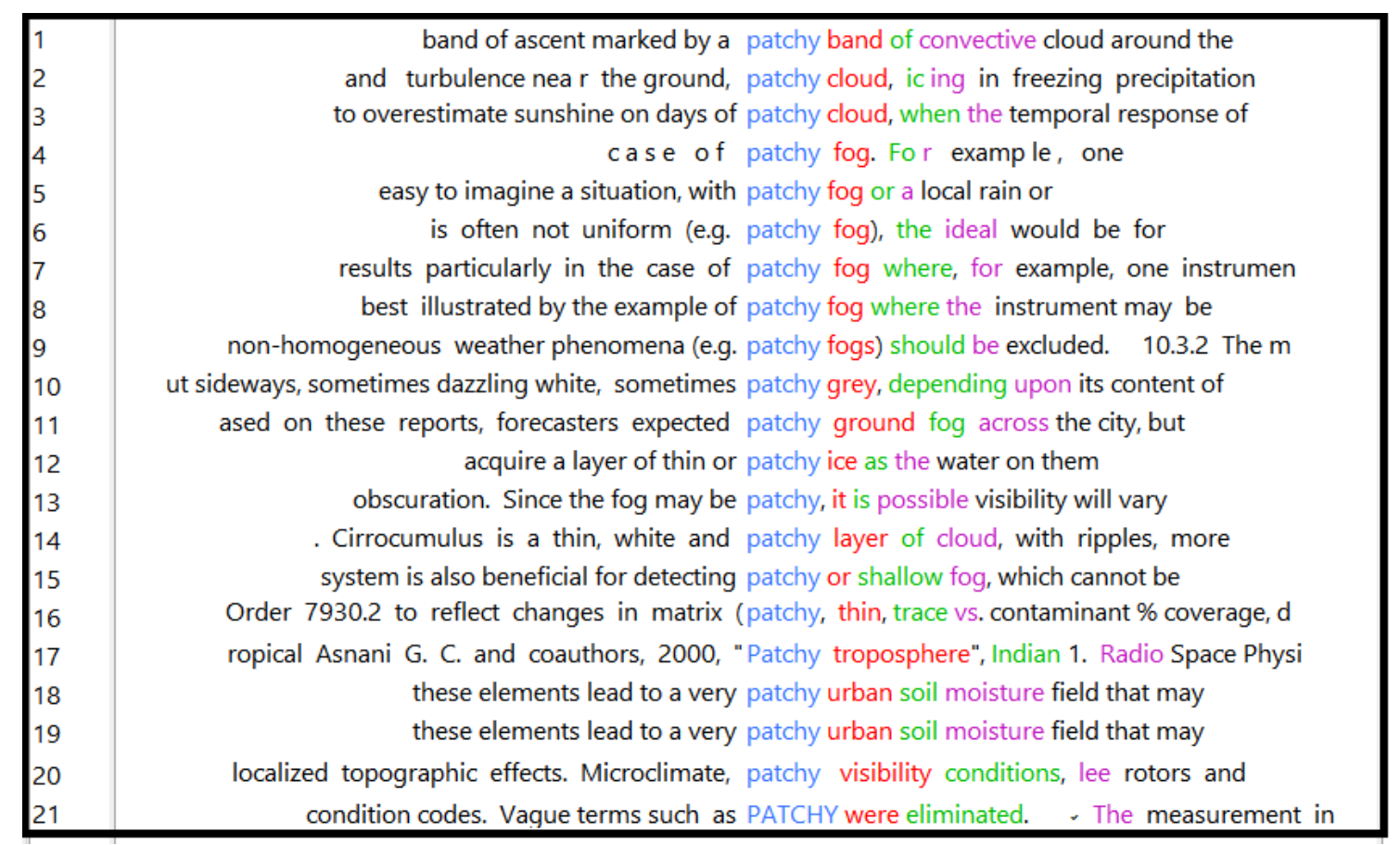

Source: Author (2020)

Concerning 'precipitation', it may occur in a sort of uniform way (intermittent or continuous) or suddenly (as showers). While the nomenclature mostly uses 'shower' when mentioning the strong and short duration of a weather phenomenon, generally associated to convective clouds (Cf. ICAO 2005), there is a grading scale for the characteristics and types of precipitation. As described in United States (2003: 2-14),

The three characteristics of precipitation are:

1. Showers - Characterized by a sudden beginning and ending, and abruptly changing intensity and/or sky conditions. Showers are associated with cumuliform clouds.

TradTerm, São Paulo, v.37, n. 1, janeiro/2021, p. 175-204 Número Especial - Linguística de Corpus www.revistas.usp.br/tradterm 
2. Continuous - Also known as steady (not showery). Intensity changes gradually, if at all. Continuous or steady precipitation is associated with stratiform clouds.

3. Intermittent - Stops and restarts at least once during the hour. Intermittent precipitation may be showery or steady, and therefore may be associated with cumuliform or stratiform clouds. (UNITED STATES 2003: 2-14).

Precipitation can take the form of drizzle; freezing drizzle; rain; freezing rain; hail or graupel; ice pellets or sleet; snow; or snow grains (Cf. UNITED STATES 2003: 2-14).

In the case of 'shower', specifically, the AER MET nomenclature may be composed of the terms and expressions 'shower', 'showery precipitation' or 'showers in the vicinity'. On this, according to WMO (2008: II.4-20), 'showers'

are characterized by their abrupt beginning and end, and by the generally rapid and sometimes violent variations in the intensity of the precipitation. Drops and solid particles falling in a shower are generally larger than those falling in non-showery precipitation. Whether the precipitation (rain or snow) occurs as showers or not depends on the clouds in which it originates (WMO 2008: II.4-20).

Then,

All precipitation other than showers must be reported as intermittent or continuous.

Non-showery precipitation usually falls from stratiform clouds (mainly altostratus and nimbostratus). Showers fall from large convective clouds (mainly cumulonimbus or cumulus of moderate or strong vertical development) and are usually characterized by their abrupt beginning and ending and by variations in the intensity of the precipitation. Drops and solid particles in a shower are generally larger than those occurring in non-showery precipitation (WMO 2008: II.4-20).

In accordance with WMO (2008), 'shower' is strongly associated with hail, as "hail always occurs in the forms of showers and is generally observed during heavy thunderstorms" (WMO, 2008: II.4-21] and never associated to 'snow grains', as "they [snow grains] usually fall in small quantities, mostly from stratus or from fog and never in the form of a shower" (Cf. WMO 2008: II.4-21).

The term 'unidentified precipitation' is particularly interesting because there is no translation to Portuguese in ICA 105-16 guidelines (BRAZIL, 2017a). The ICAO classifies 'unidentified precipitation' as cases “where intensities are

TradTerm, São Paulo, v.37, n. 1, janeiro/2021, p. 175-204 Número Especial - Linguística de Corpus www.revistas.usp.br/tradterm 
very low $(<0.1 \mathrm{~mm} / \mathrm{h})$, [and] precipitation type is not well identified" (ICAO 2011: 6-4). In such cases, 'the code 'unidentified precipitation (UP)' is often used and is preferable to an identification error" (ibidem). As corroborating this, the Annex 3, by ICAO (2018), recommends that

\begin{abstract}
In automated local routine reports, local special reports, METAR and SPECl, in addition to the precipitation types listed under 4.4.2.3 a), the abbreviation UP should be used for unidentified precipitation when the type of precipitation cannot be identified by the automatic observing system (ICAO 2018: APP 3-13).
\end{abstract}

In Portuguese, the equivalents for 'shower' or 'showery precipitation' would be 'pancada de __, while 'precipitation' is translated as 'precipitação'. It is important to note that there could be a slight difference in terms of intensity between 'shower' and 'showery precipitation' but this is not transferred to the nomenclature in Portuguese as it could sound less natural.

Another interesting point to mention is the difference between 'hail' (GR) and 'graupel', not contained in Table 4678, which seems to make 'graupel' equivalent to 'small hail and/or snow pellets' (GS), in a more simplified way.

'Hail' and 'graupel', translated to Portuguese, within a general AER MET context, as 'granizo' and 'graupel' respectively, appear in the academic literature in Portuguese, where 'graupel' is considered to be a prior stage of hail formation (Cf. MEDINA 2015) or light hail (Cf. Hallak 2007), and 'hail' is also considered a high intensity 'graupel' (Cf. RAMIREZ 2018); and in the corpus in English, where 'graupel' occurs very few times, mostly in academic and institutional training references, and a WMO publicity document, not intended to be used as a guideline.

The term 'hail' is strongly associated with 'thunderstorm', to the extent the ICAO (2016) defines that thunderstorm without hail should be classified as 'thunderstorm' only, and thunderstorm with hail should be referenced as 'thunderstorm with hail'.

The term 'thunderstorm' is translated in the Portuguese nomenclature as 'trovoada', in ICA 105-17 (BRAZIL 2017b: 114), explained in the following way: "a thunderstorm is a succession of electric discharges and thunders, generally accompanied by precipitation and always associated with CB clouds

TradTerm, São Paulo, v.37, n. 1, janeiro/2021, p. 175-204 Número Especial - Linguística de Corpus www.revistas.usp.br/tradterm 
[cumulonimbus clouds]"19. Thunderstorms are considered a less complex occurrence of 'squall lines', which are defined as "a line of violent thunderstorms" (UNITED STATES 2008: 3-14).

The definitions of Table 4678 nomenclatures highlighted here intend to shed light on some critical terms which may impact the reporting of weather phenomena in the Aeronautical Meteorological (AER MET) field, due to the fact specialized terms certainly have different uses in a daily situation and, in the case of AER MET, even in different contexts of this same field.

\section{Final considerations}

As discussed in this paper, being able to carry out a more sophisticated use of corpora may help to make best use of resources available, so this paper aimed at presenting a research methodology with set validation standards and debating nomenclatures in Aeronautical Meteorology codes.

By assuming categorization is key for an in-depth analysis, a systematization was carried out, based on linguistics with corpus assumptions (Cf. SANTOS 2008), aimed to find patterns of use in the compiled corpora, but not using a very structured statistical analysis at the moment.

Then, relying on a terminological theoretical foundation aligned with Pavel and Nolet (2001) and Cabré (1999 and 2003), this research considered a more functional approach to terminology, based on context of use and categories of documents compiled in the corpus.

In this way, the proposed corpus architecture systematized the data in six categories and used set validation standards, applied "manually", to account for the "level of authoritativeness" of each category of sources for the intended research.

This was particularly relevant due to the fact the Aeronautical Meteorology field is very specific and does not have many publications available, especially in Portuguese. So, a broader scope of sources had to be

\footnotetext{
19 "Trovoada é a sucessão de descargas elétricas e trovões, acompanhada, geralmente, de precipitação, sempre associada à nuvem CB" (BRAZIL, 2017b, original).
}

TradTerm, São Paulo, v.37, n. 1, janeiro/2021, p. 175-204 Número Especial - Linguística de Corpus www.revistas.usp.br/tradterm 
considered for this research, aimed at analyzing terminology used by official institutions, also considering language used by the professional community in other institutions and companies, which also rely on official guidelines.

By using this methodology, this paper intended to draw attention to specificities of some Aeronautical Meteorology terms, particularly on nuances regarding fog, mist and haze, and the precipitation scale to define intensity of weather phenomena. However, as the scope of this research was limited to terminology used in Table 4678, discussions are not intended to be exhaustive but only provide better understanding about the scope of use in the field, and contribute to avoid misunderstandings in communication operations.

In addition, this paper emphasizes the understanding that terminology work should be based on a theory-oriented approach to define the best strategy of compilation and analysis, and not just a translation-approach, mostly based on practice (THELEN 2015). Along with this perspective, having a high standard when compiling specialized texts and setting validation standards for a customized specialized corpus will enable proper systematization (SANTOS 2008 and 2014), by means of a scientific strategic perspective, not just a practical one.

TradTerm, São Paulo, v.37, n. 1, janeiro/2021, p. 175-204 Número Especial - Linguística de Corpus www.revistas.usp.br/tradterm 


\section{References}

American Meteorological SocietY. Glossary of meteorology. 2015. In: [Homepage]. [S.l., last update 05 Oct. 2015]. Available at: <http://glossary.ametsoc.org/wiki/Main_Page>. Accessed on: 30 Mar. 2020.

ANTHONY, L. A critical look at software tools in corpus linguistics. Linguistic Research, v.30, n.2, Seoul, 2013, pp. 141-161.

BRAZIL. ICA 105-16: meteorologia - códigos meteorológicos. Departamento de Controle do Espaço Aéreo. Ministério da Defesa. Rio de Janeiro: Comando da Aeronáutica, 2017a.

BRAZIL. ICA 105-17: meteorologia - centros meteorológicos. Departamento de Controle do Espaço Aéreo. Ministério da Defesa. Rio de Janeiro: Comando da Aeronáutica, 2017b.

CABRÉ, M. T. La terminología: representación y comunicación: elementos para una teoría de base comunicativa y outros artículos. Barcelona: Institut Universitari de Lingüística Aplicada, 1999.

CABRÉ, M. T. Theories of terminology: their description, prescription and explanation. Terminology, v. 9, n. 2, Amsterdam and Philadelphia, 2003, pp. 163-200.

CarlettA, J. Assessing agreement on classification tasks: the kappa statistic. Computational Linguistics, v. 22, n. 2, Cambridge (MA), 1996, pp. 24954.

Federal Aviation Administration. Advisory Circular AC 00-6B (Aviation Weather). Washington: U.S. Department of Transportation, 2016.

GONÇALVES, S. S. B. Open to Talk - emergências: um glossário português/inglês para as comunicações radiotelefônicas entre pilotos e controladores de tráfego aéreo. Dissertação (Mestrado em Estudos da Tradução) - Universidade de Brasília, Brasília, 2017.

GUIRAUD, P. Problèmes et Méthodes de la statistique linguistique. Paris: P.U.F., 1960.

Gultepe, I.; Sharman, R.; Williams, P. D.; Zhou, B.; Ellrod, G.; Minnis, P.; Trier, S.; Griffin, S.; Yum, S. S.; Gharabaghi, B.; Feltz, W.; Temimi, M.; Pu, Z.; StOReR, L. N.; KNeRINGer, P.; WeSton, M. J.; ChUANG, H.-Y.; ThOBOIS, L.; Dimri, A. P.; Dietz, S. J.; França, G. B.; Almeida, M. V.; Albquerque Neto, F. L. A Review of High Impact Weather for Aviation Meteorology. Pure and Applied Geophysics, v. 176, Basel (Switzerland), 2019, pp.1869-1921.

TradTerm, São Paulo, v.37, n. 1, janeiro/2021, p. 175-204

Número Especial - Linguística de Corpus www.revistas.usp.br/tradterm 
HALLAK, R. Simulações numéricas de tempestades severas na RMSP. Tese (Doutorado em Ciências) - Universidade de São Paulo, São Paulo, 2007.

Hunston, S. Corpora in Applied Linguistics. Cambridge: Cambridge University Press, 2002.

HURTADO AlBIR, A. Traducción y traductología: introducción a la traductología. Madrid: Gredos, 2001.

INTERNATIONAL CIVIL AVIATION ORGANIZATION. Working arrangements between the international civil aviation organization and the world meteorological organization. 2. ed. Montreal, 1963. (Doc 7475/2).

INTERNATIONAL CIVIL AVIATION ORGANIZATION. Manual of runway visual range observing and reporting practices. 3. ed. Montreal, 2005 [updated with amendment 2018]. (Doc. 9328).

InTERnATIONAL CiVIL AVIATION ORganizATION. Manual on automatic meteorological observing systems at aerodromes. 2. ed. Montreal, 2011 [updated with Amendment 2017]. (DOC 9837 AN/454).

International Civil aviation Organization. Air traffic management. 16. ed. Montreal, 2016. (Doc. 4444- ATM/ 501).

International CiVIL AViation Organization. Annex 3 to the Convention on International Civil Aviation. Meteorological Service for International Air Navigation: parts I and II. 20. ed. Montreal, 2018.

KILGARRIFF, A. I don't believe in word senses. Computers and the Humanities, v.31, n.2, Amsterdam, 1997, pp. 91-113.

KRIEGER, M. DA G.; FInATTO, M. J. B. Introdução à terminologia: teoria e prática. São Paulo: Contexto, 2004.

LEPRI, L. A elaboração de um glossário bilíngue para a área da aviação. Tese (Doutorado em Estudos da Tradução) - Universidade Federal de Santa Catarina, Florianópolis, 2017.

LEW, R. The Web as corpus versus traditional corpora: their relative utility for linguists and language learners. In: BAKER, P. (Ed.). Contemporary corpus linguistics. Nova York: Continuum, 2009: 289-300.

MANNING, C.; SCHÜTZE, H. Foundations of Statistical Natural Language Processing. Cambridge, MA: MIT Press, 1999.

MEDINA, B. L. Um modelo de previsão imediata de tempestades baseado em parâmetros lagrangianos medidos por radar de dupla polarização. Dissertação (Mestrado em Meteorologia) - Instituto de Pesquisas Espaciais, São José dos Campos (SP), 2015.

TradTerm, São Paulo, v.37, n. 1, janeiro/2021, p. 175-204 Número Especial - Linguística de Corpus www.revistas.usp.br/tradterm 
PaVel, S.; Nolet, D. Manual de terminologia. Traduzido por Enilde Faulstich. Québec: Bureau de la Traduction, 2001.

Peixoto, R. A. J. R. Aeronautical Meteorology Glossary: a discussion on term definition in the ANACpedia termbase. The ESPecialist, São Paulo, 2020a (in press).

Peixoto, R. A. J. R. Nas Asas da Tradução: elaboração de glossário de meteorologia aeronáutica. Revista CBTecLE, São Paulo, 2020b (in press).

Prado, M. Corpus de Inglês Oral na Aviação em situações anormais. Aviation in Focus, v.1, n.1, Porto Alegre, ago/dez 2010, pp. 48-57.

Prado, M. Levantamento dos padrões léxico-gramaticais do inglês para aviação: um estudo vetorado pela Linguística de Corpus. Dissertação (Mestrado em Estudos Linguísticos e Literários em Inglês) - Universidade Estadual de Campinas, Campinas (SP), 2015.

Prado, M. A pesquisa refletida no ensino (e vice-versa): a linguística de corpus e o inglês aeronáutico. In: SCARAMUCCI, M. V. R.; TOSQUI-LUCKS, P.; DAMIÃO, S. M. (Ed.). Pesquisas sobre inglês aeronáutico no Brasil. Campinas, SP: Pontes editores, 2018.

Prado, M.; TOSQUI-LUCKS, P. Are the LPRs focusing on real life communication issues? Dubrovnik, Croatia: International Civil Aviation English Association Workshop (ICAEA), 2017.

Prado, M.; Tosqui-LuCKS, P. Designing the Radiotelephony Plain English Corpus (RTPEC): A specialized spoken English language corpus towards a description of aeronautical communications in non-routine situations. Research in Corpus Linguistics, v. 7, Murcia (Espanha), 2019, pp.113-128.

Pustejovsky, J.; StubBS, A. Natural Language Annotation for Machine Learning. Sebastopol, CA: O'Reilly, 2013.

RABello, C. E. A terminologia de uma empresa do setor de manutenção aeronáutica: uma proposta de organização. Dissertação (Mestrado em Linguística Aplicada) - Universidade do Vale do Rio dos Sinos, São Leopoldo, 2011.

RAMIREZ, Y. M. B. Inferência de hidrometeoros a partir de um radar meteorológico de dupla polarização banda X. Dissertação (Mestrado em Ciências) - Universidade de São Paulo, São Paulo, 2018.

SAger, J. C.; L'Homme, M.-C. A model for the definition of concepts: Rules for analytical definitions in terminological databases. Terminology, v. 1, n. 2, Amsterdam and Philadelphia, 1994, pp. 351-373. 
Santos, D. Corporizando algumas questões. In: TAGnin, S. E. O.; VAle, O. A. (Eds.). Avanços da Lingüística de Corpus no Brasil. São Paulo: Humanitas/USP, 2008: 41-66.

Santos, D. Podemos contar com as contas? In: Aluísıo, S. M.; Tagnin, S. E. O. (Eds.). New Language Technologies and Linguistic Research: a two-way road. [S.l.]: Cambridge Scholars, 2014: 194-213.

TAGNIN, S. E. O. You don't need to be a specialist to translate specialized language: Corpus Linguistics can come to your rescue. 2013. (CATS Conference - Victoria, Canada).

TAGnin, S. E. O.; TeIXEIRA, E. D. British vs. American English, Brazilian vs. European Portuguese: How close or how far apart? A corpus-driven study. In: LEWANDOWSKA-TOMASZCZYK, B. (Ed.). Practical Applications in Language and Computers: PALC 2003. Frankfurt am Main: Peter Lang, 2004. pp. 193-208.

THELEN, M. The interaction between Terminology and Translation: or where Terminology and Translation meet. Lecture at the 7tn EST Congress on Translation Studies: Centres and Peripheries. Johannes Gutenberg University Mainz, 29 August - 1 September 2013: European Society for Translation Studies. Trans-Kom, v. 8, n. 2, Berlin, 2015, pp. 347-381.

TogninI-BoneluI, E. Corpus Linguistics at Work. Amsterdam and Philadelphia: John Benjamins, 2001.

Tosqul-LuCKS, P. Aplicações de corpora no ensino e na avaliação de inglês aeronáutico: estado da arte, reflexões, direcionamentos. In: SCARAMUCCI, M. V. R.; TosquI-LuCKS, P.; Damião, S. M. (Ed.). Pesquisas sobre inglês aeronáutico no Brasil. Campinas, SP: Pontes editores, 2018: 89-111.

UnITED STATES. Aviation Weather Student Guide: preflight. CNATRA P-3030 (Rev 03-03). Naval Air Training Command. Corpus Christi, TX: Department of the Navy, 2003.

World Meteorological Organization. Manual on codes: international codes. Volume I.1: annex II to the WMO technical regulations. Part A: annex II to the WMO technical regulations. Geneva, 2011. (WMO, n.306).

World Meteorological ORganization. Manual on codes: international codes. Volume I.2: annex II to the WMO technical regulations. Part B: binary codes. Part C: common features to binary and alphanumeric codes. Geneva, 2015. (WMO, n.306).

World Meteorological Organization. Aeronautical Meteorology Programme. [20?]. In: [Homepage]. Available at: <https://www.wmo.int/aemp/>. Accessed on: 30 Feb. 2020.

World METEOROLOGICAL ORGanization. Guide to meteorological instruments and methods of observation 7. ed. Geneva, 2008. (WMO-N.8).

TradTerm, São Paulo, v.37, n. 1, janeiro/2021, p. 175-204 Número Especial - Linguística de Corpus www.revistas.usp.br/tradterm 
Recebido em: 30/04/2020

Aceito em: 12/05/2020

Publicado em janeiro de 2021

TradTerm, São Paulo, v.37, n. 1, janeiro/2021, p. 175-204

Número Especial - Linguística de Corpus

www.revistas.usp.br/tradterm 